\title{
KRIMINALITETEN I ISLAND: INTERNASJONALT PERSPEKTIV ${ }^{1}$
}

\author{
Av Helgi GunNLaugsson
}

\section{INNLEDNING}

Denne artiklen knytter seg til forfatterens unders $\emptyset$ kelser om kriminaliteten i Island i de siste årene. Det fors $\varnothing$ kes å gi et innblikk i det som forfatteren selv synes er mest interessant, samtidig som det forhåpentlig gir et betydningsfullt helhetsbilde av kriminaliteten i Island. Artiklen dekker derfor ikke en bestemt unders $\varnothing$ kelse, men et videre perspektiv og på den vis belyses saken fra flere sider.

Det er viktig for alle forskere, innen for kriminologi eller andre områder, at de forsøker å knytte forskningsarbeidet til de spørsmålene som til enhver tid er mest aktuelle innenfor deres område. Og for islendingene, i dette tilfellet, å fors $\varnothing$ ke å knytte Island til andre land eller plassere det på verdenskartet. For eksempel, hvor befinner Island seg med hensyn til kriminalitet i forhold til de vestlige samfunn? Hvad med typen og omfanget av kriminaliteten? Hvordan er islendingenes subjektive oppfatning og reaksjoner på kriminalitet? Og sist, men ikke minst, hva kan kriminaliteten i Island generelt si oss om islendingene og det islandske samfunnet? Med andre ord, unders $\varnothing$ kelser skal ikke bare konsentrere seg om kriminalitet, isolert fra samfunnsomgivelsene, kriminalitet skal også brukes som et "redskap" for å si oss noe om samfunnet - se hvordan samfunnet til enhver tid formes og reflekteres i kriminaliteten.

Dessuten er det spesielt viktig i denne sammenheng å fors $\varnothing$ ke å plassere forskningsresultater innenfor teoretiske tradisjoner, det vil si at man ikke stopper opp ved innsamlingen av materialet, men streber etter å sette det $\mathrm{i}$ et teoretisk perspektiv. Nettopp dette mangler ofte i våre fag. Enten konsentrer vi oss om å samle alle slags fakta uten å plassere dem $\mathrm{i}$ en betydningsfull ramme, eller vi kaster oss ut $\mathrm{i}$ abstrakte teoretiske diskusjoner uten å ta tilstrekkelig hensyn til de empiriske faktorene. På samme måte kan man si at det ofte er et stort sprang mellom unders $\varnothing$ kelser og samfunnsmessige retninger, det vil si at forskningsresultater ofte ikke er tilstrekkelig strategisk brukt når det skal tas avgjørelser, med mindre det passer vedkommende makthaver, eller at unders $\emptyset$ kelsene simpelthen er i liten kontakt med virkeligheten. Idéelt sett burde disse to faktorene st $\varnothing$ tte og følge hverandre, det vil si unders $\varnothing$ kelser og teoretiske diskusjoner på den ene siden og unders $\varnothing$ kelser/teorier og den praktiske virkelighet på den andre.

\section{REGISTRERING AV OPPLYSNINGER OM KRIMINALITETEN I ISLAND}

Ved tidligere unders $\varnothing$ kelser av kriminaliteten i Island har det vært tydelig, at registrerte opplysninger om kriminalitet har vært mer eller mindre mangelfulle. Dette gjelder f.eks. type og frekvens av dommer som har vært publisert svært uregelmessig i dette århundret ${ }^{2}$, opplysninger fra Riksadvokaten om type og antall påtaler har ennå 
ikke blitt utgitt, og i tillegg til dette ble ikke statistiske opplysninger fra Kriminalpolitiet over antall anklager og saker utgitt før i de allersiste årene ${ }^{3}$.

Dette er selvsagt en ubehagelig situasjon som fører til at unders $\varnothing$ kelser om type og omfang av kriminaliteten blir vanskeligere enn ellers - og det blir mer problematisk å plassere Island på kartet hva kriminalitet angår. Følgelig burde man ikke være overrasket over at det fremdeles publiseres internasjonale sammenligningsundersøkelser om kriminalitetens status, der Island ikke er nevnt - kanskje fordi det har manglet tilsvarende opplysninger herfra. Visse tegn tyder på at forholdene er i ferd med å bedre seg. Som bekreftelse på dette kan nevnes at Fengselsdirektoratet systematisk har utgitt opplysninger om fengselssituasjonens status i Island fra det ble opprettet i 1989, og narkotikapolitiet har sendt ut årlige oversikter over årets virksomhet.

Hva er så de viktigste årsakene til den mangelfulle registreringen av offentlige opplysninger om kriminaliteten i Island? Er forklaringen den, at registrering av offentlige opplysninger generelt er dårlig? Eller er byråkratiseringen av det islandske samfunnet så svekket, at den gjenspeiles i en begrenset registrering av offentlige opplysninger? Forklaringen ligger ikke nødvendigvis her. Registrering av offentlige opplysninger har vært atskillig mer målbevisst på andre områder - som for eksempel om været, fiskens vandring eller fiskefangst. Årsaken ligger kanskje heller i den uprøvete teorien, at kriminaliteten har vært oppfattet som en sak som ikke er så tvingende eller påkrevet. Den har med andre ord ikke blitt oppfattet som noe stort problem hos oss, eller har ikke vært det hittil, slik at man har ment det ikke var helt nødvendig med grundig og systematisk registrering av kriminalitet. Dette har ført til at det er svært vanskelig å svare på spørsmål om hvordan kriminaliteten i Island virkelig fortoner seg sammenlignet med andre nasjoner. Forutsetningene for å kunne svare på dette spørsmålet, kunnskapene, har med andre ord ganske enkelt manglet.

\section{METODER OG PROBLEMSTILLINGER}

Hvilke råd kan man så gripe til for å unders $\varnothing$ ke kriminaliteten i Island? Er det umulig? Det trenger det slett ikke å være. I mine unders $\varnothing$ kelser har jeg fors $\varnothing \mathrm{kt}$ å løse

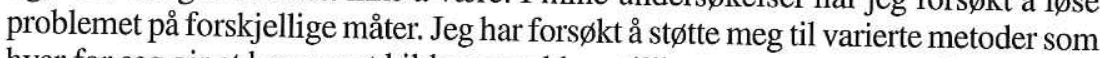
hver for seg gir et begrenset bilde av problemstillingen, men sammen danner de et totalt bilde av kriminalitetens verden i Island i dag.

Disse metodene består av å analysere de oppnåelige offisielle kildene om kriminaliteten, som for eksempel domsopplysninger og opplysninger fra politiet og Fengselsdirektoratet. Jeg har gjennomført holdningsunders $\varnothing$ kelser blant islandske borgere med spørsmål om forskjellige typer kriminalitet og folks erfaring. Så har jeg analysert pressens kriminalitetsomtale, det vil si kriminalitetnyhetenes natur og omfang $\mathrm{i}$ islandske aviser ${ }^{4}$. De burde $\mathrm{i}$ alle fall til en viss grad reflektere samfunnets kriminalitet. Dessuten har jeg satt meg inn i alltingsdebatter i forbindelse med ekspedering av saker tilknyttet kriminalitet, og st $\varnothing$ ttet meg til intervjuer med forskjellige parter som involveres i kriminaliteten. Det dreier seg for eksempel om kriminalpolitiet, dommere, fangevoktere og fanger ${ }^{5}$. 
Ved å støtte seg til så varierte metoder får man mulighet til å kaste et atskillig bredere lys på problemstillingen enn man ellers ville hatt. Som det framgikk tidligere må dette være spesielt viktig, når man tenker på den begrensete offisielle registreringen av kriminaliteten i Island. Den vanskelige situasjonen krever i praksis at man tar i bruk måter til å samle andre opplysninger om kriminaliteten enn dem man får gjennom offisielle statistikker. Også kan det nevnes at ved å støtte seg til mange metoder får man større muligheter til å danne seg både et objektivt og subjektivt bilde av Islands kriminalitetsverden. Hva mener man så med det?

Vi burde få fram et objektivt bilde av kriminalitetsutviklingen i Island slik den framstilles av de offisielle parter, og dessuten et objektivt bilde av det islandske rettsvesenets type og utvikling. I tillegg til dette objektive bildet, burde vi få innblikk i forskjellige subjektive aspekter, som hvordan islendingene føler og opplever kriminalitetsproblemene. Hva synes med andre ord islendingene selv om kriminaliteten i Island og hvordan reagerer de på den?

\section{KRIMINALITETEN I ISLAND}

Men hvor befinner islendingene seg sammenlignet med andre nasjoner med hensyn til kriminaliteten? Det har kommet fram at det på mange måter er vanskelig å svare dette spørsmålet med sikkerhet, men vi kan trygt kaste fram den hypotesen at i lyset av en internasjonal sammenligning med andre vestlige land, befinner antallet av alvorlige forbrytelser i Island seg i den nederste kanten.

ITabel 1 er noen eksempler som bekrefter dette, bygt på politiets data for 1993 per 100.000 innbyggere ${ }^{6}$ :

\begin{tabular}{lccrrrr} 
By & Drap & Voldtægt & Alvorl. vold & Tyveri & Narkotika & Ran \\
\hline Reykjavik & 0.9 & 10.0 & 3.4 & 3.3 & 163.1 & 29.3 \\
København & 2.8 & 15.0 & 283.0 & 17.0 & 2196.0 & 331.2 \\
Oslo & 2.5 & 17.5 & 67.6 & 9.8 & 735.0 & 214.2 \\
Stockholm & 5.5 & 28.7 & 53.0 & 15.3 & 655.0 & 268.0 \\
Helsingfors & 2.2 & 13.2 & 41.6 & 8.5 & 230.0 & 169.4 \\
\hline
\end{tabular}

Mordfrekvensen hører til de lavere man kjenner til eller ca. ett mord pr. år i forhold til 100 tusen innbyggere 7 . Ran forekommer sjelden, bare fire ble tiltalt for ran i 1985 og seks i 1987. Væpnet ran forekommer også sjelden og organisert profesjonell forbrytervirksomhet har ingen røtter her på det vis som vi kjenner til mange steder i utlandet. Selv om vi kan se spor av noe som likner på organisert forbrytervirksomhet i Island, virker det som om profesjonalisering av kriminaliteten er liten. Det er mange narkotikalovbrudd, men forholdsvis få av den alvorlige sorten.

I boka si: "Cities With Little Crime" påstod Clinard" at Sveits var et land uten store forbrytelser til tross for industrialisering og tettbebyggelse. Balvig9 argumenterte mot dette $\mathrm{i}$ den interessante boka sin og påpekte, at Sveits i realiteten var lite bedre enn andre land i Vesteuropa hva angikk kriminalitetshyppighet. Kanskje hadde Island 
vært en verdigere kandidat enn Sveits som landet med de få forbrytelsene, men det er langt fra sannheten at Island er et slags forbryterfritt paradis. Noe slikt er i realiteten utenkelig, som Durkheim ${ }^{10}$ påpekte ved siste århundreskiftet. Islendingene har for eksempel økende bekymring for utviklingen av kriminaliteten, noe holdningsunders $\emptyset$ kelsene mine klart har tilkjennegitt. Denne vurderingen stemmer helt overens hos både allmennheten, myndighetene og politietaten, og de bekymringene virker større hos islendingene enn sveitserne selv om de sannsynligvis er vant til flere alvorlige forbrytelser enn vi.

Men hvilke saksgrupper har vært omfangsrike innenfor det islandske rettssystemet? Hvilke lovbrudd er det som peker seg ut hos oss og kanskje vitner om et større problem enn man kjenner til hos andre vestlige nasjoner?

\section{LOVBRUDD TILKNYTTET ALKOHOLFORBRUK}

I en unders $\emptyset$ kelse jeg gjennomf $\varnothing$ rte om islendingenes $\varnothing$ lforbud for noen år siden fikk jeg straks innblikk $i$ det store problemet som myndighetene mener islendingenes alkoholforbruk $\mathrm{er}^{11}$. Senere har jeg funnet ut at disse bekymringene har flere vidder som blant annet kommer til syne gjennom islendingenes rettshåndhevelse. Eksempler som bekrefter dette er for eksempel, at politiet hvert år arresterer tusenvis av berusete personer i Reykjavik, en by med 100 tusen innbyggere. Politiet i Reykjavik arresterte gennemsnitlig 2270 personer i 1990-1994 for offentlig beruselse, og av disse trengte tusener å overnatte i politicelle. I det hele kan nevnes, at omtrent halvdelen af alle opphold i Reykjavik politis fengselsceller i denne periode gjaldt beruselse på offentlige områder ${ }^{12}$.

Hvert år blir tusener arrestert for promillekjøring. I perioden 1974-1990 ble gjennomsnittlig 2459 individer arrestert pr. år for dette ${ }^{13}$. Dette betyr i realiteten at ca. en prosent av hele den islandske befolkningen hvert år blir arrestert for promillekjøring, hvad det er en betydelig høyere andel enn i det $\varnothing v$ vige Norden ${ }^{14} . \mathrm{Og}$ det reageres strengt på slike brudd. Ved tredje arrestasjon risikerer man et fengselsopphold. De siste årene har andelen av slike fanger passert en fjerdedel av alle straffangene i Island ${ }^{15}$.

Disse forholdene viser tydelig at myndighetene bruker mye tid på å motarbeide beruselse og en stor del av politiarbeidet ser ut til å gå med til denne kategorien. Dette gir oss også et vink om at i Island har alkoholrelaterte problemer nådd et alvorlig stadium. Til en viss grad har de nok det ${ }^{16}$. Det som på den annen side taler imot denne vurderingen, er de offentlige opplysningene om islendingenes alkoholvaner, som viser at tross en $\varnothing \mathrm{kning}$ i alkoholkonsumet, drikker de i betydelig mindre grad enn nesten alle andre vestlige nasjoner ${ }^{17}$ - selv om omfanget av denne kategorien i Island likevel er nevneverdig og det samme kan sies om debatter og kontroll med landets drikkevaner.

\section{NARKOTISKE STOFFER I ISLAND}

Islendingenes bekymring for alkoholmisbruket retter seg også mot andre berusende stoffer. Her mener jeg faren som de mener følger med utbredelsen av de narkotiske 
stoffene i samfunnet. I en meningsmåling, som jeg for noen år siden gjennomførte i samarbeid med institutt for sosial forskning ved Islands Universitet, kom dette klart fram. For eksempel mente ca. 40 prosent i 1989 at narkotikamisbruk var et av de alvorligste kriminelle problemene i Island og 31 prosent i $1994^{18}$. I tillegg bærer det $\emptyset \mathrm{kte}$ antallet av kriminalnyheter som er tilknyttet narkotika, preg av $\emptyset \mathrm{kt}$ bekymring om sakenes utvikling. I 1969 handlet for eksempel 6 prosent av kriminalnyhetene $\mathrm{i}$ landets største avis om narkotika, mens denne andelen var kommet opp på 20 prosent i $1989^{19}$.

Islandske myndigheter synes å være av samme mening som allmennheten og massemediene, og de har reagert kraftig etter at disse stoffene første gangen dukket opp i Island rundt 1970-tallet ${ }^{20}$. Det ble bl.a. opprettet en egen narkotikadomstol og et spesielt politikorps som bare skulle ta seg av narkotikasaker under domstolens formelle ansvar. Denne bestemmelsen gikk på tvers av islandsk lovgivning som sier at doms- og politimyndighet skal være adskilt. Det viser hvor alvorlig myndighetene så på narkotikainvasjonen. Spesielle og selvstendige tiltak ble tatt $\mathrm{i}$ bruk for å demme opp, selv om bestemmelsene ikke fulgte juridiske vaner ${ }^{21}$.

I 1992 ble det foretatt omfattende endringer i rettsvesenet i Island. De gikk blant annet ut på nedlegge narkotikadomstolen i overenstemmelse med allmenn lovgivning. Narkotikapolitiet fortsetter som før, og i 1995 var det politiets største spesialkorps med 18-19 ansatte ${ }^{22}$.

Myndighetenes raske reaksjon og islendingenes holdning til alvoret bak narkotikamisbruket, frister en til å trekke den raske konklusjonen at problemer som knyttes til narkotiske stoffer ligger på et høyt nivå i Island. Det kan så være, for eksempel tyder narkotikapolitiets arrestasjoner på dette med gjennomsnittlig ca. 400 arresterte pr. år i perioden 1987-1994, mistenkt for narkotikabrudd. På den annen side er de fleste av arrestasjonene knyttet til eget forbruk, bare få dreier seg om import og salg av narkotiske stoffer. Samtidig tyder politiets rapporter om beslaglagte stoffer på, at de fleste sakene knytter seg til cannabisbruk, noe få andre nasjoner kan tillate seg å bruke mye penger eller tid på. Hardere stoffer som heroin og crack er nærmest ukjente i Island, mens amfetamin har fătt fotfeste i enkelte mindre samfunnsgrupper ${ }^{23}$.

Som andre steder i Vesteuropa kjennetegnes narkotikamisbrukernes bakgrunn i høy grad av arbeidsledighet eller at vedkommende kommer fra en ufaglært arbeiderklasse - og dette i langt høyere grad enn andelen til disse gruppene tilkjennegir ellers i samfunnet. For eksempel sa 40 prosent av de arresterte i 1990 at de var arbeidsledige, mens arbeidsledigheten i samme tidsrom i landet ellers var på 1-2 prosent. Narkotikamisbruk ser ut til å følge dem som befinner seg i utkanten av samfunnet og er til en viss grad betegnende for dem som har kommet i problemer. Kanskje har de større vansker med å frigjøre seg fra politiet enn andre samfunnsgrupper.

Unders $\varnothing$ kelser både fra inn- og utland tyder likevel på at narkotikaproblemet i Island ikke er like alvorlig som i mange vestlige land. Her kan det nevnes at medisinske unders $\varnothing$ kelser har vist, at forgiftninger og dødsfall i Island som følge av ulovlige narkotiske stoffer, hører til de laveste man kjenner til i den vestlige verden ${ }^{24}$. I en unders $\varnothing$ kelse som Forskningsentret for pedagogiske spørsmål foretok av unge men- 
nesker i 1994, viste det seg at under 5 prosent av elevene i den videregående skolen $i$ alderen 16-20 år sa at de hadde prøvd cannabis oftere enn 10 ganger og at under 20 prosent hadde prøvd cannabis en gang $^{25}$, hvad det ikke adskiller sig stort fra de andre nordiske landene ${ }^{26}$. Til sammenlikning kan nevnes, at 54 prosent av 17 årige elever i USA (senior high school students) fortalte at de hadde prøvd cannabis i $1985^{27}$. Utbredelsen av narkotiske stoffer ser derfor ikke ut til å være så stor. Dette kan man kanskje delvis takke myndighetenes raske reaksjon og islendingenes generelle negative holdning til narkotika ${ }^{28}$. Likevel syns vi problemene som følger narkotika er store nok.

\section{ISLENDINGENES BEDØMMELSE AV ÅRSAKEN TIL KRIMINALITETEN}

Det er en annen side av denne problemstillingen som jeg vil nevne her og den er tilknyttet holdningen til rusmidler. I intervjuer jeg har foretatt med personer innenfor rettssystemet, som for eksempel politi, dommere, ansatte i justisdepartementet og fangevoktere, foruten fangene selv, kommer det klart fram at bakgrunnen for Islands kriminalitet ligger i misbruk av rusmidler og oppløsning av hjemmene som følge av dette. Andre forklaringer som $\varnothing$ konomiske problemer, fattigdom eller samfunsmessig ubalanse, nevnes mye sjeldnere ${ }^{29}$.

Denne oppfatningen kom også klart fram i den tidligere nevnte meningsmålingen. Ca. 76 prosent mente i 1994 at misbruk av rusmidler og vanskelige forhold i hjemmet var hovedårsaken til Islands kriminalitet. Bare 7 prosent nevnte $\varnothing$ konomiske problemer i stedet. Det virker derfor som om det er allmenn enighet om at roten til kriminaliteten heller ligger i individenes personlige problemer enn i samfunnets type eller utvikling.

Totalt sett utgjør rusmidler en av de største kategoriene innenfor rettssystemet, og er if $\varnothing$ lge mange en av de viktigste grunnene til at islendingene begår lovbrudd. Rusmidler er derfor både et av de vanligste lovbruddene, samtidig som de oppfattes som en av de viktigste grunnene til at folk begår lovbrudd.

\section{TEGN PÅ KRIMINALITETSENDRINGER}

Det er ikke mulig å forlate denne diskusjonen uten å komme inn på visse endringer som har funnet sted i kriminalitetsutviklingen de siste årene, og samtidig fors $\varnothing \mathrm{ke} a ̊$ forklare islendingenes stadig $\varnothing$ kende bekymring for denne.

Fra 1970-tallet har drap nærmest vært en årlig begivenhet, ofte med flere enn ett, mens det tidligere fant sted med 5-10 års mellomrom ${ }^{30}$. Vinnings- og $\varnothing$ konomiske forbrytelser er blitt omfangsrikere og mer kompliserte og i tillegg har vi fătt narkotikasakene $^{31}$. Samtidig har håndteringen av forbrytelsene i stor grad $\varnothing \mathrm{kt}$ de siste årene og mange mener at de har blitt grovere og utføres av mindre anledning enn tidligere.

Min bedømmelse er at denne utviklingen reflekterer Islands kompliserte og hurtige samfunnsendringer, som har forandret både indre og ytre struktur i de siste årtier. Innenfra har det islandske samfunnet endret seg med mer industrialisering, arbeid og bosetning, med tilhørende tettbebyggelsesmønster. Samtidig har Island åpnet seg mot omverdenen og brutt den geografiske isoleringen med $\varnothing \mathrm{kt}$ samferdsel og inter- 
nasjonale forbindelser. Dette har medført utenlandsk påvirkning som for eksempel narkotika.

Til tross for de siste års samfunnsendringer mener jeg fremdeles at Island befinner seg nede på den vestlige skalaen hva angår type og omfang av alvorligere kriminalitet. Kriminalitetsutviklingen i Island vil i framtiden bli preget av de samfunnsomgivelsene vi kommer til å få.

\section{FORKLARINGER PÅ KRIMINALITETEN I ISLAND}

Sosialvitenskapenes rolle er ikke bare å beskrive virkeligheten eller samle fakta. Like viktig er søkingen etter å forklare denne virkeligheten. Det er særlig to saker som jeg $\emptyset$ nsker å belyse her.

1) Hvorfor er islendingene så opptatt av rusmisbruk?

2) Hvorfor er antall alvorlige forbrytelser i Island lavere enn i mange andre vestlige samfunn?

Hva angår det første spørsmålet er det rett å påpeke at mange andre land, særlig de nordlige, har en liknende bekymring om rusmisbruk. I tillegg oppdaget jeg $\mathrm{i}$ forbindelse med min tidligere nevnte $\varnothing$ lforbudsunders $\varnothing$ kelse, at disse bekymringene kan føres langt tilbake $\mathrm{i}$ landets historie, det bærer litteraturen og de gamle sagaene preg av. I Alltingsdebatten i forbindelse med $\varnothing$ lforbudet kom det stadig fram at islendingene simpelten ikke kunne omgås brennevin på en fornuftig måte. De mister herredømmet, og vikingblodet fikk av og til skylden ${ }^{32}$. Det kan kanskje ha noe for seg, likevel er det en kjennsgjerning at islandske myndigheter gjennom tidene har fors $\varnothing \mathrm{kt}$ mange råd for å begrense adgangen til alkohol.

I denne sammenheng er det nødvendig å ha i tankene, at mange av Islands mektigste menn i det 19. og 20. århundret fikk sin politiske oppdragelse i ungdoms- og avholdsbevegelser som hadde stor innflytelse langt inn i dette århundret. Dette resulterte i forskjellige politiske foranstaltninger for å hindre alkoholholdige drikker.

Hva angår narkotiske stoffer, så er det et internasjonalt problem. I Island ser man dette ennå tydligere ettersom nasjonen er fåtallig og isolert, og narkotiske stoffer blir oppfattet som en utenlandsk trussel med opprinnelse i fjerne land og de later seg vanskelig dyrke her. Narkotika blir derfor oppfattet som en fare som kommer utenfra og muligens kan $\varnothing$ delegge denne homogene nasjonen.

Islendingene har derfor reagert kraftig og samstemmig mot denne faren. Dette har kanskje hjulpet oss fra de farligste sidene ved disse problemene, som riker mange andre steder.

\section{KRIMINALITETEN I ISLAND I INTERNASJONALT PERSPEKTIV}

Det siste spørsmålet jeg vil ta opp, dreier seg om hvorfor antall alvorlige forbrytelser som drap, væpnet ran og grove narkotikaforbrytelser er lavere i Island enn i mange andre vestlige samfunn. 
I kriminologien har det ofte vært påpekt at i fåmenne og kulturelt homogene samfunn kan man forvente mindre kriminalitet ${ }^{33} \mathrm{og}$ det passer til en viss grad på islendingene. De er fåtallige og kulturelt homogene med få nasjonale minoritetsgrupper eller religiøse sekter. I samfunn med mange raser og religiøse sekter kommer det ofte opp kulturkollisjoner med derav følgende kriminalitet. I tillegg gir fåtallighet $\varnothing \mathrm{kte}$ muligheter til primær gruppetilhørighet, som mange ansette kriminologer, som f.eks. Nils Christie ${ }^{34}$ mener er en forutsetning for profilakse mot kriminalitet. En slik sosial tilknytning fører til samhørighet og respekt for hverandre.

Det er også andre samfunnsmessige egenskaper ved Island som utvilsomt reduserer kriminaliteten: Vi har en integrert sosial struktur som har vært preget av likevek $\mathrm{t}^{35}$. Vi har aldri hatt konged $\varnothing \mathrm{mme}$ eller arvelige priviligerte klasser som lenseller adelsystem, hvilket utvilsomt har styrket samholdet. Kampen mot naturkreftene har også knyttet folk sammen og gjort dem mindre opptatt av sosiale klasseforskjeller. Fattigkvarterer eksisterer ikke. Og som i Skandinavia har både utdannelse og helse vært en del av folks rettigheter og ikke for noen få priviligerte.

Andre nasjonalegenskaper fra Islandshistorien de siste århundrene kan også nevnes som forklaring på den lave alvorlige kriminaliteten. Islendingenes selvstendighetskamp mot Danmark var preget av fredsommmelighet og ivektlegging av lovene ${ }^{36}$. Det var ingen blodige kamper, liv som gikk tapt eller folk som ble fengslet. Islendingene fikk sin selvstendighet ved å bruke logikk og argumentasjon. Danskene hørte på fornuft, og vi unngikk de blodige krigene som så mange andre nasjoner har måttet gjennomgå.

Det kan også ha noe å si at islendingene ikke har hatt militær. Våpenlisens er begrenset $\mathrm{og}$ ikke vanlig. Verken politi eller fangevoktere bærer våpen. Alt bærer preg av fredsommelighet og fredelig innstilling. Det har heller ikke vært noen blodige uoverenstemmelser mellom forskjellige sosiale grupper i Island. Derfor har nok massemedienes oppslag om vold i Reykjaviks sentrum det siste halvåret kommet som et sjokk for mange. De er ikke vant til å få dette inn på seg, selv om vold ikke er noe nytt i Island.

Totalt sett kan man slå fast at islendingene bor i et forholdsvis fredelig samfunn med en homogen sosial og kulturell bagrunn. Denne fører sannsynligvis til færre alvorlige forbrytelser enn i mer kompliserte samfunn. Min konklusjon er derfor, at forklaringen på kriminaliteten og løsningen ligger i samfunnsmessige og kulturelle omgivelser, og ikke bare i lovbestemmelsenes isolerte verden og en repressiv straffepolitikk.

\section{Fotnoter:}

1) Forfatteren takker Nordisk Samarbejdsråd for Kriminologi for ytet støtte ved bearbeidelsen af denne artiklen, som iblandet nye data er opbygd på mit foredrag på NSfKs forskerseminar i maj 1994 i Halvorsbøle, Norge: "Islendingenes forhold til kriminalitet".

2) Olafsdottir, Hildigunnur (1985). Kriminalitetstendenser i Island. Nordisk Tidsskrift for Kriminalvidenskab. April, 72. årgang. Nr. 2: 81-100. 
3) Islands kriminalpolitis første årsrapport var for 1990 og siden har det hvert år utgitt liknende rapporter over antallet og typene af saker.

4) Gunnlaugsson, Helgi (1996). Empiri og ideologi i kriminologi: Den objektive og subjektive siden av kriminaliteten i Island. Nordisk Tidsskrift for Kriminalvidenskab. Marts, 83. årgang. Nr. 1:14-26.

5) Gunnlaugsson, Helgi (1992). The Social Reality of Crime in Iceland: Criminal Punishment in a Land with Little Crime. Avhandling fra universitetet i Missouri, Columbia, USA.

6) Interpols årsrapport, 1993, Reykjavik politi, 1995.

7) Archer, D. og Gartner, R. (1984). Violence \& Crime in Cross-National Perspective. Yale University Press, New Haven og London.

8) Clinard, Marshall (1978). Cities With Little Crime: The Case of Switzerland. London, England: Cambridge University Press.

9) Balvig, Flemming (1988). The Snow-White Image: The Hidden Reality of Crime in Switzerland. Oslo: Norsk universitetsforlag.

10) Durkheim, Emile (1964). The Division of Labor. New York Free Press.

11) Gunnlaugsson, Helgi og Galliher, J. (1987). Om symbolsk politik och ölforbudet på Island. Alkoholpolitik: Tidskrift for Nordisk Alkoholforskning, 4, 117-124.

12) I henhold til statistisk oversikt fra Reykjavik politi.

13) Rapport om ferdselsulykker i Island 1990 (1991). Traffikrådet, Reykjavik.

14) Nordic Alcoholic Statistics 1989-1993 (1994). ALKO Alcohol Policy Planning and Information, November, Helsinki.

15) Jf. Islands fengselsdirektorats årsrapporter, hvor fengselsopphold for sprittkørsel faller under "umferdarlagabrot/nytjataka".

16) Jf. The Icelandic Medical Journal, 74. årg., nr. 4, april, 1988, fx Olafsdottir, H. og Helgason, T. "Innlagnir a medferdarstofnanir vegna misnotkunar afengis og annarra vimuefna 1975-1985".

17) Trends in Alcohol and Drug Use in Sweden (1993). Report 93. Swedish Council for Information on Alcohol and other Drugs. National Institute of Public Health. Stockholm.

18) Jf. henvisning 4).

19) Jf. henvisning 5).

20) Gunnlaugsson, Helgi og Galliher, J. (1995). The Secret Drug Police of Iceland. I Undercover: Police Surveillance in Comparative Perspective. G. Marx og Fijnaut (red.) Kluwer.

21) Thormundsson, Jonatan (1980). Opinbert rettarfar. 2. hæfte, 2. utgave. Reykjavik.

22) Skyrsla um fikniefna- og afbrotamalefni (1996). Reykjavik politi og informasjon og driftsdiagrammer fra Reykjavik politi.

23) Bygd på Reykjavik narkotikapolitis årsrapporter 1987-1994.

24) The Icelandic Medical Journal (1991). Rannsoknir a lyfjaeitrunum a Borgarspitala 198788, Nr. 10:384, desember.

25) Kaldalons, I., Sigurdardottir, Th. og Bjarnason, Th. (1994). "Vimuefnaneysla framhaldsskolanema 1992-94". Rannsoknarstofnun uppeldis- og menntamala.

26) Jf. fx henvisning 17).

27) Bachman, J. et.al. (1986). Changes in Marihuana Use Linked to Change in Perceived Risks and Disapproval. Monitoring the Future, Occasional Paper No. 19. Institute for Social Research, Ann Arbor: University of Michigan.

28) Olafsson, Stefan og Jonsson, F. (1991). "Lifsskodun i nutimathjodfelögum". Felagsvisindastofnun Haskola Islands. 
29) Jf. henvisning 5).

30) Hardardottir, Ragnheidur (1991). "Um brot gegn 211. grein Almennra hegningarlaga". Ulfljotur, 48, årg., Nr. 1:43-54.

31) Kristmundsson, Omar (1989). "Refsivistardomar og fullnusta theirra. Gæsluvardhald". Doms- og kirkjumalaraduneytid.

32) Jf. henvisning 11).

33) Adler, Freda (1983). Nations Not Obsessed With Crime. Littleton, Colorado: Fred B. Rothman and Company.

34) Christie, Nils (1993). Crime Control as Industry: Towards Gulags Western Style. London: Routledge.

35) Visbending (1994). "Er mikill tekjumunur a Islandi?" Ukeskrift om handel og $\emptyset$ konomi. 12. årg. Nr. 44.

36) Grimsson, Olafur R. og Broddason, Th. (1977). Islenska thjodfelagid. Reykjavik: Felagsvisindadeild H.I. og Örn og Örlygur.

Adresse: Helgi Gunnlaugsson, Ph.d., lektor,

Sociologisk fakultet, Haskoli Islands,

IS-101 Reykjavik, Island.

E-post: helgigun@rhi.hi.is 